\title{
Vulnerabilidade ocupacional e social nas grandes metrópoles brasileiras
}

\author{
Occupational and social vulnerability \\ in large Brazilian metropolises
}

Inaiá Maria Moreira de Carvalho [l] Cláudia Monteiro Fernandes [II]

\section{Resumo}

Este artigo aborda a evolução recente da vulnerabilidade ocupacional e social nas grandes metrópoles brasileiras, associando essa evolução às características do processo de urbanização e desenvolvimento do País, e, mais especificamente, às transformações econômicas, sociais e políticas das décadas iniciais deste novo milênio. Com base em dados da PNAD sobre as taxas de desemprego, a inserção ocupacional, a cobertura previdenciária e a remuneração dos trabalhadores, o texto confirma como essa vulnerabilidade se reduziu entre 2004 e 2015 nos grandes centros estudados, mas evidencia, também, como esse fenômeno se interrompeu no período posterior. Assinala como esse período tem sido marcado pelo avanço do desemprego, da precariedade ocupacional e da pobreza, ressaltando, finalmente, como as tendências e as perspectivas para os próximos anos são preocupantes.

Palavras-chave: vulnerabilidade; trabalho; pobreza; dinâmica socioeconômica; metrópoles brasileiras.

\begin{abstract}
This article discusses the recent evolution of occupational and social vulnerability in the largest Brazilian metropolises, associating this evolution with the characteristics of the country's urbanization and development processes, and, more specifically, with the economic, social and political transformations that took place in the early decades of this new millennium. Based on data from the National Household Sample Survey on unemployment rates, occupational insertion, social security coverage and labor income, the text shows that this vulnerability was reduced between 2004 and 2015 in the large centers, and that this phenomenon was interrupted in the subsequent period. The analysis points out that this period has been marked by the advance of unemployment, occupational precariousness and poverty, and highlights that the trends and prospects for the coming years are worrisome.
\end{abstract}

Keywords: vulnerability; labor; poverty; socioeconomic dynamics; Brazilian metropolises. 


\section{Introdução}

Este artigo se propõe a discutir como evoluem as condições de vulnerabilidade ocupacional e social nas grandes metrópoles brasileiras no início deste novo milênio, transformando-as no epicentro da crise social do País na atualidade. Iniciando essa discussão, vale lembrar que as transformações contemporâneas do capitalismo, com o colapso do fordismo e a emergência de um novo regime de acumulação, a mundialização da economia, a financeirização da riqueza e o avanço das ideias e das políticas neoliberais têm levado a uma multiplicação das incertezas, das crises econômicas, das desigualdades e das carências sociais. Nessa nova fase de expansão do sistema, mesmo nos países centrais, vêm ocorrendo uma relativa desconstrução e um enfraquecimento das articulações virtuosas entre o mercado, a democracia e a cidadania social que marcaram a constituição da sociedade salarial e do Estado de Bem-Estar Social, conforme ressaltam autores como Castel (2012) ou Kerstenetzky (2012), entre vários outros.

Com a redução das funções reguladoras e das responsabilidades sociais do Estado, uma nova ênfase na lógica e nos mecanismos do mercado e uma profunda reestruturação do mundo do trabalho, as sociedades vêm se tornando cada vez mais expostas e vulneráveis aos ataques e aos efeitos destrutivos dos "moinhos satânicos" (Polanyi, 2000), com o retorno de condições de exploração, carência e exclusão que pareciam ter sido superadas nas socialdemocracias mais consolidadas do capitalismo e que, tardiamente, vinha se buscando superar na periferia ou na semiperiferia do sistema.
Tendências à desindustrialização e à redução das oportunidades de trabalho, crescimento do desemprego, erosão do contrato salarial e uma restrição de políticas redistributivas e sociais têm levado aos países desenvolvidos condições ocupacionais e sociais até então consideradas como típicas das áreas subdesenvolvidas e atribuídas ao seu atraso, como a expansão do denominado subproletariado. Contudo a trajetória e as condições desses países e a profunda internalização dos direitos de cidadania na sua cultura política têm colocado limites ao domínio da lógica do mercado, às políticas neoliberais, à precarização dos vínculos ocupacionais, ${ }^{1}$ à superexploração dos trabalhadores e à desconstrução do seu sistema de proteção social.

Bem diferente é a situação de países como o Brasil, que não chegaram a constituir plenamente uma sociedade salarial e um Estado de Bem-Estar e onde as grandes metrópoles concentram especialmente a população, a riqueza e o poder, mas são marcadas, sobretudo, pela dimensão de problemas como a vulnerabilidade e a precariedade das condições ocupacionais e sociais da maioria da sua população. Abordando a dimensão e a evolução desses problemas de 2004 até 2018, período que abrange diferentes conjunturas, este artigo analisa as condições de atividade e ocupação, a cobertura trabalhista e previdenciária, os rendimentos dos trabalhadores e a evolução da pobreza nas dez maiores metrópoles brasileiras, baseando-se, principalmente, em tabulações especiais dos dados das PNADs. ${ }^{2}$ As análises e considerações obtidas a partir desses dados são apresentadas no presente texto, que, além desta Introdução, compreende mais três outras seções. A primeira menciona como 
os problemas de ocupação e vulnerabilidade se configuram e evoluem ao longo do processo de desenvolvimento e de urbanização do País; a segunda reporta-se mais especificamente à realidade das regiões metropolitanas no período em discussão; e a terceira apresenta algumas considerações finais.

\section{Ocupação e vulnerabilidade social no desenvolvimento brasileiro}

Como se sabe, os processos brasileiros de desenvolvimento e a urbanização vêm tendo um caráter desigual e excludente, sendo incapazes de oferecer melhores condições de ocupação, integração e subsistência à sua numerosa população. Ao longo desse desenvolvimento, apesar de grande expansão e diversificação da estrutura produtiva e ocupacional da rede urbana, a relação contratual assalariada e regulada por direitos trabalhistas e sociais nunca chegou a se universalizar. A abundância de mão de obra e a dimensão do exército de reserva viabilizaram tanto a compressão salarial como a coexistência entre o "tradicional" e o "moderno", com a persistência de relações de trabalho precárias em setores como o pequeno comércio ou o serviço doméstico. Como assinala Faria (1976), ao longo do processo de urbanização do País, mesmo nas suas áreas mais desenvolvidas e dinâmicas, uma reduzida camada de alta renda e camadas médias urbanas ampliadas e diversificadas passaram a conviver com o proletariado industrial e com um vasto e heterogêneo contingente de trabalhadores pobres, de vida incerta e duvidosa.
Ao lado de fatores como a rapidez do processo de urbanização, os interesses do capital imobiliário e a fraca capacidade de regulamentação e de redistribuição do Estado, isto contribuiu para a conformação de cidades extremamente desiguais, segregadas e excludentes conforme ressaltado por autores como Kowarick (1979 e 2008), Villaça (1998), Ribeiro (2017a e 2017b) ou Rolnick (2015). Cidades em que as camadas de alta e média renda se concentram em áreas mais centrais, com uma melhor disponibilidade de infraestrutura e serviços, enquanto a maioria dos trabalhadores, atingida por um processo de "espoliação urbana" (Kowarick, 1979), vem tendo que enfrentar a questão da habitação através da autoconstrução de moradias precárias em periferias distantes, desprovidas de equipamentos e serviços básicos, onde subsistem em condições de vulnerabilidade socioeconômica e civil (Kowarick, 2008).

Até a década de 1970, porém, o extraordinário desenvolvimento do País, com taxas de crescimento do Produto Interno Bruto (PIB) superiores ao crescimento da População Economicamente Ativa (PEA), em uma época em que a expansão da produção implicava maior demanda de trabalho, ampliou as possibilidades de uma melhor integração ocupacional e social, especialmente nas grandes cidades.

Mas a tendência a uma melhor integração através do mercado foi revertida, na década de 1980, com o esgotamento do padrão de desenvolvimento até então implementado. Com o agravamento da crise econômica, a crise fiscal do Estado e uma intensa aceleração do processo inflacionário, os caminhos do Brasil foram reorientados, com a implantação de um conjunto de políticas convergentes, afinadas 
com os princípios neoliberais. Denominadas "ajuste estrutural", "reformas estruturais" ou reformas orientadas para o mercado, elas envolveram um processo de estabilização, uma abertura econômica intensa e rápida, um amplo programa de privatizações, uma ênfase maior nos mecanismos de mercado e uma reformulação do papel do Estado. Não apenas em termos do seu protagonismo econômico e de suas funções reguladoras como, também, de suas responsabilidades como provedor de políticas sociais.

Com isso, o quadro social do País agravou-se dos anos 1990 aos primeiros anos deste novo milênio, em um período marcado por baixos níveis de crescimento econômico, deterioração das condições de ocupação e renda da população, reorientação regressiva das políticas sociais e acentuação das históricas desigualdades socioeconômicas e espaciais. Rompeu-se o que Cardoso (2004) denomina a "promessa integradora do mercado formal de trabalho", que marcou o período desenvolvimentista, segundo a qual a economia em crescimento constante incluiria, com o tempo, todos os assalariados em relações de emprego reguladas pelo setor público, garantindo direitos trabalhistas e sociais, assim como uma representação de interesses em negociações coletivas.

A abertura e a reestruturação produtiva, com uma inserção passiva e subordinada do País na economia global, foram associadas a uma expressiva destruição de postos de trabalho, notadamente no setor industrial. Com a constituição de uma economia de base urbano-industrial no Brasil, há décadas que tanto a população rural como a ocupação na agropecuária têm se reduzido. Na medida em que a indústria também restringiu o emprego de mão de obra, o setor de serviços passou a absorver um maior número de trabalhadores, mas muitos deles através do pequeno comércio, da prestação de serviços pessoais e de outras atividades precárias e malremuneradas.

Esse conjunto de mudanças se traduziu na ampliação do tradicional excedente de mão de obra no País, em um grande crescimento do desemprego, na precarização das relações de trabalho e na queda do rendimento dos que permaneceram ocupados. Discutindo a evolução do mercado de trabalho na década de 1990, estudos de Pochmann (2001) e de Pochmann et al. (2004) ressaltam que se, nos anos $1980,96,1 \%$ das pessoas que se inseriram no mercado de trabalho encontraram uma vaga, nos anos 1990, esse percentual caiu para $62,5 \%$. Dos 13,6 milhões de pessoas que ingressaram no mercado de trabalho nesses últimos anos, apenas 8,5 milhões tiveram acesso a algum posto de trabalho, gerando um excedente de 5,1 milhões de trabalhadores. Além disso, diversamente do que ocorrera nas décadas anteriores, nos anos 1990, a maioria dos postos criados não possuía um registro formal, o que representou uma profunda e adversa alteração na qualidade desses postos, uma vez que apenas os empregos com registro oferecem uma proteção trabalhista e social.

Em 2001, os empregados representavam não mais que $47,8 \%$ da população ocupada no Brasil, e boa parte deles não possuía um vínculo formalizado. Com a expansão de atividades precárias e malremuneradas, como o pequeno comércio, o emprego doméstico e a prestação de serviços pessoais, os trabalhadores por conta própria constituíam 22,3\% daquela população; os trabalhadores domésticos, 7,8\%; os militares 
e estatutários, 6,8\%; os empregadores, 4,2\%; e os não remunerados 7,4\%. Em 2003, esse quadro praticamente não se alterou. Os empregados eram novamente $47,8 \%$ dos ocupados, e apenas $62,6 \%$ tinham registro em carteira. Os trabalhadores por conta própria eram $22,4 \%$, e não mais que $14,8 \%$ deles contribuíram para a previdência social; os trabalhadores domésticos participavam com 7,7\%; os militares e estatutários, com 6,6\%; os empregadores, com 4,2\%; e os não remunerados, com $7,1 \%$, conforme dados das PNAD de 2001 e 2003 apresentados em estudo de Carvalho (2006).

Em uma conjuntura marcada pela reestruturação produtiva e por um alto desemprego, as empresas introduziram novos padrões de organização de produção e de gestão da mão de obra, utilizando principalmente o mecanismo de uma massiva terceirização. 0 próprio Estado passou a utilizar esses expedientes, com a transferência de algumas de suas funções para as denominadas "organizações sociais", e o recurso a forma "atípicas" de contratação. Apregoava-se a necessidade de reduzir a intervenção governamental na regulação das relações de trabalho (que estariam se caracterizando pela rigidez, aumentando o custo da mão de obra e reduzindo a competitividade da economia nacional) e na proteção aos trabalhadores, promovendo a sua flexibilização. Como assinala Borges (2016), o discurso oficial chegou a proclamar o "fim dos empregos" e a chegada da era do "empreendedorismo", cabendo agora aos próprios trabalhadores assegurar a sua competitividade e "empregabilidade" em um mercado de trabalho e uma economia sempre em mudança e que exige novas habilidades e competências, investindo continuadamente na sua qualificação.
Nesse contexto, cresceram o desemprego, a informalidade, a precariedade ocupacional e o número de pobres e indigentes. $\mathrm{E}$, diante desse quadro e na contramão dos princípios universalistas e dos avanços conquistados com a Constituição de 1988 no Brasil, as políticas sociais limitaram-se basicamente a desenvolver ações emergenciais, limitadas e focalizadas sobre os segmentos mais pauperizados da população, como bem ressaltam as ricas análises de Ivo (2008). A esse respeito, aliás, Cardoso Jr. $(2011$, p. 30) assinala que a proposta de universalidade da cobertura das políticas sociais não se firmou totalmente, "nem como princípio ideológico geral e tampouco como prática do Estado na implementação concreta de tais políticas", conforme estabelecido pela Constituição. Reconhecendo avanços de natureza jurídico-legal e efetiva na ampliação da cobertura nas áreas de educação, saúde e seguridade social, o autor destaca, porém, que a referida implementação foi sendo condicionada, desde a década de 1990, pela combinação de fatores macroeconômicos e políticos, que resultaram na configuração de uma agenda pautada por cinco diretrizes básicas: universalização restrita, privatização da oferta de serviços públicos, descentralização da sua implementação, aumento da participação não governamental na sua provisão e focalização sobre a pobreza extrema em algumas áreas da política social. Essas diretrizes permaneceram nos anos 2000.

A vitória de uma aliança partidária liderada por forças historicamente vinculadas à classe trabalhadora na eleição presidencial de 2002 levou a uma certa mudança do padrão de gestão da economia e das questões sociais no País, com mudanças nas condições acima assinaladas. Beneficiado por uma conjuntura 
internacional favorável e pelo crescimento da demanda e dos preços das commodities, o novo governo manteve alguns dos pilares da política econômica do seu antecessor, mas recuperou o papel do Estado como indutor do desenvolvimento econômico; ampliou os investimentos públicos; e estimulou a expansão de diversas cadeias produtivas, desenvolvendo, paralelamente, políticas ativas para viabilizar o crescimento e a formalização do emprego e a geração de renda, mesmo fora do assalariamento. ${ }^{3}$ Promoveu uma elevação do valor real do salário mínimo, expandiu o crédito e tomou outras medidas que levaram à ampliação do mercado interno, viabilizando o ingresso de miIhões de novos consumidores nesse mercado e impulsionando o comércio, a indústria e o setor de serviços.

Conformou-se um círculo virtuoso que levou à recuperação e a um crescimento da economia, associados a uma melhoria das condições sociais, conforme constatado por estudos como o de Dedecca (2015), Montalli e Lessa (2016), Borges (2016), Singer e Loureiro (2017) e Singer (2018) e Carvalho (2018), entre vários outros. A nova dinâmica favoreceu, sobretudo, os trabalhadores mais pobres, aumentando suas chances de acesso a um emprego protegido, com salários médios elevados pelos ganhos reais do salário mínimo, que passara a ser considerado como uma variável básica para o crescimento da economia e para a redução da pobreza e das desigualdades sociais. 0 impacto dessa nova política salarial foi dos mais relevantes, entre outros fatores, porque o salário mínimo constitui um salário de referência para o conjunto de empregados (mesmo aqueles sem registro formal em carteira) e para os trabalhadores autônomos, uma vez que ele foi adotado como piso básico para benefícios previdenciários e sociais. ${ }^{4}$

0 modelo de desenvolvimento do País, com ênfase na produção de commodities, não foi capaz de gerar empregos de maior qualidade na quantidade necessária para incorporar os trabalhadores mais escolarizados. Postos com melhores salários e possibilidades de carreira ficaram concentrados em alguns setores de atividade e no serviço público, como nas universidades e outros segmentos da sua administração. ${ }^{5}$ Expandiram-se, sobretudo, empregos com remunerações de no máximo até dois salários mínimos em ocupações menos qualificadas, como vendedores, prestadores de serviços, e trabalhadores da construção civil, uma vez que o modelo de crescimento com distribuição de renda tem limitações. Ao estimular o consumo interno, seria necessário garantir a estrutura produtiva para atender à nova demanda, seja por serviços ou por produtos industriais, portanto, seria necessária uma política industrial voltada para a diversificação da estrutura produtiva, o que não aconteceu. 0 setor de serviços que mais cresceu no período teve um aumento de demanda que fez com que os preços crescessem mais que os demais setores (inflação de serviços), com menor influência do mercado externo de commodities, o que permitiu um repasse de preços para os consumidores de média e baixa renda, interrompendo o ciclo virtuoso distributivo das políticas de aumento de salários e investimentos sociais (Carvalho, 2018).

Ainda assim, a conjuntura em apreço foi marcada por políticas de combate à pobreza extrema, mesmo que restritas, e por uma expansão das políticas e dos gastos sociais. Programas focalizados iniciados no governo 
anterior foram unificados e ampliados, no que se refere tanto ao volume de gastos quanto ao número de seus beneficiários. Conforme documento do Ipea (2016b), o patamar de gastos sociais no Brasil passou de 36 para 74 bilhões de reais entre 2006 e 2015 (respectivamente de $14,2 \%$ para $17,5 \%$ do PIB), ${ }^{6}$ com uma grande expansão na cobertura dos beneficiários. É verdade que esses gastos continuaram bem abaixo dos padrões de países mais desenvolvidos: em 2016, eles representavam $31,5 \%$ do PIB na França, 24,1\% em Portugal, 21,5\% na Grã-Bretanha, 19,3\% nos Estados Unidos. ${ }^{7}$ Contudo, o mais importante dos programas sociais do período, o Bolsa Família, teve o seu orçamento ampliado de 570 milhões para 7,5 bilhões de reais, passando a atender 11,4 milhões de famílias nesse último ano, enquanto o Benefício de Prestação Continuada - BPC assistia a 2,4 milhões de idosos e deficientes em situação de extrema pobreza (Singer e Loureiro, 2017, p. 64 e p. 68). E outros programas e iniciativas também contribuíram para ampliar o acesso da população mais pobre a serviços básicos, como água, energia elétrica, telefone, assistência médica e educação.

Após a estagnação de 2003, o PIB teve um crescimento de 5,7\% em 2004, 6,1\% em 2007, 5,1\% em 2008 e 7,5\% em 2010 (Singer, 2012, p. 150). A melhoria do desempenho macroeconômico foi associada a um crescimento do emprego e da sua formalização, com um aumento dos rendimentos médios dos trabalhadores e do seu acesso aos direitos trabalhistas e sociais, contribuindo para a redução da vulnerabilidade e para a elevação dos níveis de proteção social. Com base na PNAD anual, entre 2002 e 2014 o número de ocupados passou de 79,7 para 99,5 milhões de pessoas; o desemprego caiu de 9,2\% para 6,9\%; a proporção de empregados com carteira assinada subiu de $54 \%$ para $64,2 \%$; e a de ocupados contribuintes para a previdência, de 45,2\% para $61,2 \% .{ }^{8}$ Conforme estudos de Waldir Quadros, citados por Singer (2018, p. 82), o contingente de miseráveis caiu de 24\% em 2002 para 7,5\% em 2014, tornando-se residual, e a pobreza também se reduziu de forma não desprezível, embora ainda atingisse cerca de $33 \%$ da população, uma vez que a maioria dos miseráveis apenas ascendera a condição de pobres. ${ }^{9}$ Registrou-se, igualmente, uma tendência à redução da desigualdade, com a queda do índice de Gini de 0,60 para 0,53, ainda que essa redução fosse limitada e não se traduzisse em uma mudança no padrão de concentração vigente no País, conforme assinala Dedecca (2015).

Como se sabe, porém, as condições que viabilizaram esses avanços não conseguiram se sustentar. Tanto em decorrência da crise internacional de 2008 (que afetou a demanda e os preços das commodities e reduziu as possibilidades de crescimento de diversos países, a exemplo do Brasil), como das suas próprias contradições internas, o ciclo expansivo que marcou a trajetória do País na primeira década deste novo milênio terminou por se esgotar. $A$ economia desacelerou e as medidas adotadas para estimular o seu crescimento não surtiram maiores efeitos positivos; as contas públicas se deterioraram; os investimentos governamentais se restringiram; e o consumo retraiu-se, paralelamente a uma elevação da inflação, do déficit fiscal e da dívida pública, como analisa Carvalho (2018), principalmente em decorrência dos gastos financeiros.

A crise econômica (sinalizada em 2009, em decorrência dos efeitos adversos da crise 
mundial de 2008) agravou-se entre 2015 e 2016, associada a uma crise política sem precedentes, ao crescimento da insatisfação social e da rejeição à presidente, à fragilidade de sua base de apoio, aos impactos da operação "Lava Jato"10 e a uma intensa mobilização das forças conservadoras (inclusive da referida base) para inviabilizar e derrubar 0 governo. Com o êxito dessa mobilização e o impeachment da presidente eleita, uma nova coalizão política assumiu o poder, apresentando como a grande alternativa para a retomada do crescimento econômico e a melhoria das condições de vida da população "uma ponte para o futuro" que redefinia os rumos do País, com uma radicalização dos princípios e orientações neoliberais.

Para o alcance desses objetivos, o novo governo passou a promover um conjunto de ajustes econômicos, políticos e institucionais, que abrem caminhos para um projeto de crescimento desembaraçado dos princípios e compromissos de regulação e proteção social e dos avanços obtidos a partir da Constituição de 1988. Princípios e compromissos que, como ressalta o clássico estudo de Polanyi (2000), são indispensáveis para proteger a sociedade, a natureza e a própria organização produtiva das consequências deletérias do livre jogo das forças do mercado. Contudo, dois anos após essas reorientações (marcados por medidas como a retomada das privatizações, a aprovação da Emenda Constitucional - EC 55, a limitação de gastos por 20 anos a partir de 2016, com efeitos adversos apontados por estudos como os do Ipea,2016a e 2016b, a reforma trabalhista e a proposição de uma dura reforma da previdência), o que se observa está muito longe das promessas do novo governo.
A "ponte" vem mantendo o País em condições de crise e estagnação, com uma queda do índice de crescimento econômico de 3,5\% em 2016 (repetindo a queda de 2015), uma elevação para apenas 1\% em 2017 e previsões, para 2018, de ser mantido praticamente esse percentual; milhares de empregos formais foram destruídos, o desemprego e a precariedade ocupacional se ampliaram e, em maio de 2018, a Organização Internacional do Trabalho (OIT) colocou o Brasil na lista dos 24 casos das principais violações das convenções trabalhistas no mundo. Considerada como a "lista suja" da entidade, ela inclui tradicionalmente problemas de liberdade sindical, assassinato de líderes trabalhistas ou irregularidades na aplicação de convenções da OIT (Chade, 2018). A vulnerabilidade ocupacional e social se agravou e, como seria de esperar, isto se refletiu nas grandes regiões metropolitanas.

\section{As regiões metropolitanas brasileiras}

Tanto a necessidade de uma certa concentração espacial de infraestrutura e serviços como a trajetória e as características do processo de industrialização e de desenvolvimento do Brasil levaram à sua concentração em algumas áreas e centros urbanos. Diversificando a sua estrutura produtiva, transformando-se em ponto de ancoragem das grandes empresas, estimulando o crescimento das atividades terciárias e das oportunidades de trabalho e de obtenção de renda e atraindo intensos fluxos migratórios, alguns deles terminaram por assumir uma configuração metropolitana e por concentrar uma 
proporção elevada da produção, da população e da riqueza nacional.

Como assinalam Moura, Delgado, Dechamps e Cardoso (2004), em 1970, São Paulo e Rio de Janeiro conformavam amplas áreas metropolitanas, onde se encontrava, respectivamente, $15,6 \%$ e $13,2 \%$ da população urbana do País. Belém, Belo Horizonte, Curitiba, Fortaleza, Porto Alegre, Recife e Salvador, que desempenhavam a função de capitais de Estado, abrigavam outros $16,7 \%$, evidenciando que o fenômeno da metropolização se ampliava, mas sem romper o hiato que distingue esse conjunto de cidades, uma vez que a industrialização e a constituição de um mercado nacional unificado estabeleceram uma divisão inter-regional do trabalho que acentuou as desigualdades inter e intrarregionais no País, privilegiando alguns estados e metrópoles do centro-sul.

Contudo, nas décadas de 1960 e, especialmente, nos anos 1970, o avanço do processo de substituição de importações, políticas de desenvolvimento regional, implementadas pelo governo federal, e inversões de grandes empresas estatais, entre outros fatores, promoveram maiores articulação e complementaridade entre os diversos espaços que compõem a nação brasileira, contribuindo para uma certa descentralização das atividades produtivas e para 0 crescimento e modernização de algumas áreas, como as grandes capitais nordestinas, que assumiram uma configuração mais efetivamente metropolitana. ${ }^{11}$ Com a evolução desses processos, no ano 2000, São Paulo e Rio de Janeiro (consideradas, respectivamente, como a "cidade global" e a "gateway city" do Brasil) e suas respectivas regiões abrigavam 28,6 milhões de pessoas, representando $17 \%$ da população do País. As regiões metropolitanas polarizadas por metrópoles "nacionais" (ou seja, Fortaleza, Recife, Salvador, Belo Horizonte, Curitiba e Porto Alegre) e pelo Distrito Federal agregavam outros 23,1 milhões, correspondendo a 13,6\% dos brasileiros (ibid.). Com a agregação de Belém, esses espaços constituem as dez maiores metrópoles do Brasil. Em 2010, segundo dados do último Censo, elas abrigavam 31,3\% da população do País e, em 2015, 30,8\%, de acordo com a Pesquisa Nacional por Amostra de Domicílios.

Em termos econômicos, essas áreas concentravam mais de $42 \%$ do PIB nacional em 2015, e a região metropolitana de São Paulo representava mais de $17,6 \%$ do PIB nacional. Além disso, algumas dessas metrópoles têm sido especialmente beneficiadas na medida em que as transformações contemporâneas vêm contribuindo para ampliar o papel e a relevância desse tipo de aglomerações, que passam a representar sítios estratégicos para a dinâmica dos seus países na economia em rede que emerge com a globalização e a reestruturação produtiva, conforme ressalta Veltz (1986), concentrando funções de coordenação, comando e direção, atividades financeiras e novos serviços de ponta.

Mas em que pese a sua diversidade em termos de tamanho, estrutura produtiva e nível do desenvolvimento, essas regiões não vêm propiciando melhores condições de ocupação, renda e subsistência para uma parcela significativa da sua população. Notadamente após 0 esgotamento do padrão de desenvolvimento implementado até a década de 1980 e o ajuste e as reformas que marcaram a década de 1990 e os primeiros anos deste novo século, período marcado, como foi visto, por baixos níveis de 
Tabela 1 - Pessoas de 10 anos ou mais, economicamente ativas, desempregadas e taxa de desemprego - Brasil e Regiões Metropolitanas 2004

\begin{tabular}{l|c|c|c}
\hline \multirow{2}{*}{ Brasil e Região Metropolitana } & \multicolumn{2}{|c|}{ População (em mil) } & $\begin{array}{c}\text { Taxa de Desemprego } \\
\text { (Des/PEA) }\end{array}$ \\
\cline { 2 - 3 } & Total (PEA) & Desempregados & 8,9 \\
\hline Brasil & 93.564 & 8.318 & 14,4 \\
Distrito Federal & 1.149 & 165 & 11,7 \\
Belém & 957 & 112 & 13,1 \\
Fortaleza & 1.611 & 211 & 17,8 \\
Recife & 1.650 & 293 & 19,4 \\
Salvador & 1.920 & 372 & 12,1 \\
Belo Horizonte & 2.538 & 308 & 11,9 \\
Rio de Janeiro & 5.522 & 657 & 14,0 \\
São Paulo & 9.880 & 1.384 & 8,1 \\
Curitiba & 1.647 & 134 & 8,9 \\
Porto Alegre & 2.106 & 187 & \\
\hline
\end{tabular}

Fonte: IBGE - Pesquisa Nacional por Amostra de Domicílios anual.

crescimento econômico, expressiva destruição de postos e precarização das relações de trabalho, deterioração das condições de renda de vários segmentos de trabalhadores, crescimento do desemprego e da vulnerabilidade social (Carvalho, 2006).

No período analisado no presente texto, a população persistia crescendo, assim como a população economicamente ativa e a taxa de atividade nessas regiões. Contudo, refletindo as dificuldades e os problemas de integração produtiva antes mencionados, com a exceção de Curitiba e Porto Alegre, mesmo nas metrópoles mais dinâmicas e afluentes as taxas de desemprego eram superiores a 10\%, em 2004, elevando-se especialmente em casos como os de Recife e Salvador.

A posição na ocupação e a cobertura previdenciária do contingente de ocupados também evidenciam a precariedade das condições laborais de grande parte dos trabalhadores.
Embora as áreas estudadas apresentassem uma situação relativamente mais favorável que o conjunto do país, a parcela de ocupados por conta própria (condição associada, na grande maioria dos casos, ao exercício de atividades precárias e malremuneradas), de trabalhadores domésticos e trabalhadores não remunerados era expressiva nessas áreas. Com a exceção do Distrito Federal explicada pelo peso da administração pública na sua estrutura ocupacional, o contingente de empregados não chegava a $70 \%$, inclusive em metrópoles como São Paulo, Belo Horizonte, Curitiba e Porto Alegre. Uma grande parcela de trabalhadores encontrava-se excluída de proteção trabalhista e social, notadamente em casos como os de Fortaleza, Recife e Belém, onde os contribuintes para a previdência no trabalho principal ou em qualquer trabalho constituíam menos de metade dos ocupados no ano de 2004, conforme os dados das Tabelas 2 e 3. 
Tabela 2 - Pessoas de 10 anos ou mais de idade, ocupadas, por posição na ocupação no trabalho principal

\begin{tabular}{|c|c|c|c|c|c|c|c|c|c|c|c|c|}
\hline \multirow{3}{*}{$\begin{array}{l}\text { Brasil e Região } \\
\text { Metropolitana }\end{array}$} & \multicolumn{12}{|c|}{ Posição na Ocupação } \\
\hline & \multicolumn{2}{|c|}{ Empregado } & \multicolumn{2}{|c|}{ Trab. doméstico } & \multicolumn{2}{|c|}{ Empregador } & \multicolumn{2}{|c|}{ Conta própria } & \multicolumn{2}{|c|}{$\begin{array}{l}\text { Trab. não } \\
\text { remunerado }\end{array}$} & \multicolumn{2}{|c|}{ Outros $^{2}$} \\
\hline & N & $\%$ & N & $\%$ & $\mathrm{~N}$ & $\%$ & $\mathrm{~N}$ & $\%$ & N & $\%$ & N & $\%$ \\
\hline Brasil & 46.969 & 55,1 & 6.515 & 7,6 & 3.500 & 4,1 & 18.740 & 22,0 & 5.986 & 7,0 & 3.536 & 4,1 \\
\hline Distrito Federal & 693 & 70,4 & 108 & 11,0 & 41 & 4,2 & 135 & 13,7 & 7 & 0,7 & 0 & 0,0 \\
\hline Belém & 433 & 51,2 & 93 & 11,0 & 30 & 3,6 & 253 & 29,9 & 32 & 3,8 & 4 & 0,5 \\
\hline Fortaleza & 838 & 59,9 & 135 & 9,6 & 50 & 3,6 & 313 & 22,4 & 49 & 3,5 & 15 & 1,1 \\
\hline Recife & 815 & 60,1 & 125 & 9,2 & 44 & 3,2 & 341 & 25,1 & 22 & 1,6 & 10 & 0,7 \\
\hline Salvador & 919 & 59,4 & 162 & 10,5 & 54 & 3,5 & 359 & 23,2 & 39 & 2,5 & 15 & 1,0 \\
\hline Belo Horizonte & 1.394 & 62,5 & 223 & 10,0 & 94 & 4,2 & 408 & 18,3 & 27 & 1,2 & 84 & 3,8 \\
\hline Rio de Janeiro & 3.070 & 63,1 & 459 & 9,4 & 169 & 3,5 & 1118 & 23,0 & 39 & 0,8 & 10 & 0,2 \\
\hline São Paulo & 5.809 & 68,4 & 681 & 8,0 & 351 & 4,1 & 1520 & 17,9 & 95 & 1,1 & 40 & 0,5 \\
\hline Curitiba & 945 & 62,5 & 108 & 7,1 & 82 & 5,4 & 300 & 19,8 & 40 & 2,6 & 38 & 2,5 \\
\hline Porto Alegre & 1.241 & 64,7 & 130 & 6,8 & 106 & 5,5 & 375 & 19,5 & 31 & 1,6 & 36 & 1,9 \\
\hline
\end{tabular}

Fonte: IBGE. Pesquisa Nacional por Amostra de Domicílios anual.

Notas: ${ }^{1}$ Números absolutos em mil; ${ }^{2}$ Inclui Trabalhadores na produção para o próprio consumo e na construção para o próprio uso.

Tabela 3 - Pessoas de 10 anos e mais, empregadas, por contribuição para instituto de previdência em todos os trabalhos

\begin{tabular}{l|r|r|r|r|r|c}
\hline \multirow{2}{*}{ Brasil e Região Metropolitana } & \multicolumn{6}{c}{ Contribuintes } \\
\cline { 2 - 7 } & \multicolumn{2}{|c|}{2004} & \multicolumn{2}{c}{2011} & \multicolumn{2}{c}{2015} \\
\cline { 2 - 7 } & $\mathbf{N}$ & $\%$ & $\mathbf{N}$ & $\%$ & $\mathrm{~N}$ & $\%$ \\
\hline Brasil & 39.550 & 46,4 & 55.451 & 58,5 & 58.813 & 61,7 \\
Distrito Federal & 654 & 66,4 & 987 & 74,6 & 1.063 & 75,2 \\
Belém & 337 & 39,9 & 491 & 51,9 & 519 & 52,6 \\
Fortaleza & 628 & 44,8 & 950 & 54,8 & 1.043 & 60,6 \\
Recife & 679 & 50,1 & 1.007 & 67,8 & 1.017 & 64,0 \\
Salvador & 789 & 51,0 & 1.166 & 62,5 & 1.222 & 64,7 \\
Belo Horizonte & 1.367 & 61,3 & 1.890 & 72,9 & 1.911 & 72,5 \\
Rio de Janeiro & 2.944 & 60,5 & 3.837 & 69,7 & 3.786 & 68,6 \\
São Paulo & 5.305 & 62,4 & 7.441 & 73,1 & 7.684 & 75,3 \\
Curitiba & 937 & 61,9 & 1.262 & 71,5 & 1.307 & 76,6 \\
Porto Alegre & 1.239 & 64,6 & 1.560 & 74,4 & 1.620 & 76,6 \\
\hline
\end{tabular}

Fonte: IBGE, Pesquisa Nacional por Amostra de Domicílios anual.

Nota: Números absolutos em mil. 
Como seria de esperar, as condições assinaladas refletiam-se principalmente na remuneração dos trabalhadores. Como a tabela a seguir deixa patente, uma boa parcela das pessoas de 10 anos e mais ocupadas recebia rendimentos até meio ou até um salário mínimo, notadamente nos casos de metrópoles menos industrializadas e desenvolvidas, como Belém, Fortaleza, Recife e Salvador. Tanto nessas áreas, como em Belo Horizonte, a maioria dessas pessoas tinha ganhos até duas vezes o mínimo e, com exceção do Distrito Federal, no conjunto das metrópoles estudadas, o total daqueles que recebiam acima desse valor não chegava à metade dos trabalhadores ocupados. Vale lembrar que até a política da sua valorização que veio a ser implementada, o salário mínimo equivalia a apenas US\$86,46 dólares em 2004, chegou a valer US\$326,35, em 2011, e passou a US\$235,93, em 2015. ${ }^{12}$

Como mencionado, porém, a eleição de 2002 e a ascensão ao poder de uma aliança partidária mais vinculada às demandas da classe trabalhadora levaram a mudanças nesse quadro, com a recuperação do crescimento econômico, e a mudanças nas condições sociais do País. A melhoria do desempenho econômico foi associada a uma ampliação do emprego e da sua formalização, a um maior acesso dos trabalhadores aos direitos trabalhistas e sociais e a um aumento dos seus rendimentos médios, e, como seria de esperar, isto se refletiu sobre os centros metropolitanos em discussão.

Tabela 4 - Pessoas com 10 anos ou mais de idade, ocupadas e com rendimento, por classes de rendimento mensal no trabalho principal

\begin{tabular}{|c|c|c|c|c|c|c|c|c|c|c|}
\hline \multirow{3}{*}{$\begin{array}{l}\text { Brasil e Região } \\
\text { Metropolitana }\end{array}$} & \multicolumn{10}{|c|}{ Classes de rendimento mensal do trabalho principal ${ }^{1}$} \\
\hline & \multicolumn{2}{|c|}{ Até $1 / 2$ SM } & \multicolumn{2}{|c|}{ Mais de $1 / 2$ a $1 \mathrm{SM}$} & \multicolumn{2}{|c|}{ Mais de 1 a 2 SM } & \multicolumn{2}{|c|}{ Mais de 2 a 5 SM } & \multicolumn{2}{|c|}{ Mais de $5 \mathrm{SM}$} \\
\hline & $\mathrm{N}$ & $\%$ & $\mathrm{~N}$ & $\%$ & $\mathrm{~N}$ & $\%$ & $\mathrm{~N}$ & $\%$ & $\mathrm{~N}$ & $\%$ \\
\hline Brasil & 8.165 & 9,6 & 15.950 & 18,7 & 24.371 & 28,6 & 17.646 & 20,7 & 8.219 & 9,6 \\
\hline Distrito Federal & 26 & 2,6 & 109 & 11,1 & 318 & 32,3 & 236 & 24,0 & 274 & 27,8 \\
\hline Belém & 94 & 11,1 & 227 & 26,9 & 254 & 30,1 & 154 & 18,2 & 66 & 7,8 \\
\hline Fortaleza & 174 & 12,4 & 417 & 29,8 & 426 & 30,4 & 199 & 14,2 & 108 & 7,7 \\
\hline Recife & 185 & 13,6 & 348 & 25,6 & 415 & 30,6 & 220 & 16,2 & 133 & 9,8 \\
\hline Salvador & 213 & 13,8 & 384 & 24,8 & 458 & 29,6 & 270 & 17,4 & 130 & 8,4 \\
\hline Belo Horizonte & 148 & 6,6 & 384 & 17,2 & 770 & 34,5 & 491 & 22,0 & 267 & 12,0 \\
\hline Rio de Janeiro & 194 & 4,0 & 593 & 12,2 & 1.579 & 32,5 & 1.419 & 29,2 & 746 & 15,3 \\
\hline São Paulo & 219 & 2,6 & 749 & 8,8 & 2.643 & 31,1 & 2.858 & 33,6 & 1.523 & 17,9 \\
\hline Curitiba & 53 & 3,5 & 170 & 11,2 & 500 & 33,0 & 474 & 31,3 & 228 & 15,1 \\
\hline Porto Alegre & 75 & 3,9 & 205 & 10,7 & 668 & 34,8 & 581 & 30,3 & 294 & 15,3 \\
\hline
\end{tabular}

Fonte: IBGE. Pesquisa Nacional por Amostras de Domicílio anual. Nota: ${ }^{1}$ Números absolutos em mil. 
A taxa de desemprego reduziu-se de 14,4\%, em 2004, para 7,8\%, em 2011, no Distrito Federal; de 11,7\% para 10,9\%, em Belém; de $13,1 \%$ para $6,2 \%$, em Fortaleza; de $17,8 \%$ para $12,0 \%$ em Recife; de $19,4 \%$ para $13,5 \%$, em Salvador; de $12,1 \%$ para $6,8 \%$, em Belo Horizonte; de $11,9 \%$ para $8,0 \%$, no Rio de Janeiro; de $14,0 \%$ para 7,2\%, em São Paulo; de $8,1 \%$ para $4,7 \%$, em Curitiba; e de $8,9 \%$ para 5,3\% em Porto Alegre, ainda que milhares de novos trabalhadores tenham se agregado à população economicamente ativa no período em questão. Ampliou-se o número de empregados e decresceu relativamente a participação dos ocupados em condições precárias, como os empregados sem uma formalização do vínculo, a maioria dos trabalhadores por conta própria, os trabalhadores domésticos e os não remunerados, inclusive naquelas metrópoles menos industrializadas e desenvolvidas, como Belém, Fortaleza, Recife e Salvador.

0 contingente de contribuintes para a previdência ampliou-se (elevando o nível de proteção social), passando de $63,3 \%$ para $74,6 \%$ dos empregados no Distrito Federal; de $39,7 \%$ para $51,8 \%$ em Belém; de $44,7 \%$ para $54 \%$ em Fortaleza; de 49,9\% para 67,7\% em Recife; de $50,7 \%$ para $62,3 \%$ em Salvador; de $61,1 \%$ para $72,6 \%$ em Belo Horizonte; de $60,2 \%$ para $69,6 \%$ no Rio de Janeiro; de $62,4 \%$ para 73,0\% em São Paulo; de 61,7\% para $71,3 \%$ em Curitiba; e de $64,5 \%$ para $74,2 \%$ em Porto Alegre. Esse aumento foi um indicador de formalização crescente do mercado de trabalho. Mais da metade dos trabalhadores era empregados, e mais de $60 \%$ dos empregados

Tabela 5 - Pessoas de 10 anos ou mais, economicamente ativas, desempregadas, e taxa de desemprego

\begin{tabular}{l|c|c|c}
\hline \multirow{2}{*}{ Brasil e Região Metropolitana } & \multicolumn{2}{|c|}{ População (em mil) } & \multirow{2}{*}{$\begin{array}{c}\text { Taxa de Desemprego } \\
\text { (Des/PEA) }\end{array}$} \\
\cline { 2 - 3 } & Total (PEA) & Desempregados & 6,7 \\
\hline Brasil & 101.586 & 6.823 & 7,8 \\
Distrito Federal & 1.435 & 112 & 10,9 \\
Belém & 1.062 & 116 & 6,2 \\
Fortaleza & 1.849 & 115 & 12,0 \\
Recife & 1.688 & 203 & 13,5 \\
Salvador & 2.157 & 292 & 6,8 \\
Belo Horizonte & 2.783 & 189 & 8,0 \\
Rio de Janeiro & 5.982 & 480 & 7,2 \\
São Paulo & 10.979 & 792 & 4,7 \\
Curitiba & 1.853 & 88 & 5,3 \\
Porto Alegre & 2.215 & 117 & 6 \\
\hline
\end{tabular}

Fonte: IBGE - Pesquisa Nacional por Amostra de Domicílios anual. 
contribuíam para a previdência em, pelo menos, um dos trabalhos realizados. Essa cobertura cresceu tanto em termos absolutos como em termos relativos até 2015 (Tabela 3). No entanto, é importante ressaltar que quase $40 \%$ dos ocupados tinham cobertura bem menor de contribuição para a previdência. A análise dos dados após 2015, com a PNAD contínua, trará ao debate a cobertura para todos os ocupados, e não apenas para os empregados.

A distribuição dos ocupados por classes de rendimento mensal no trabalho principal também evidencia como as condições ocupacionais se tornaram mais favoráveis para os trabalhadores da base da pirâmide social, confirmando o caráter "pró-pobre" que alguns autores atribuem ao crescimento econômico do período em discussão. Os ocupados que percebiam até meio salário mínimo experimentaram um decréscimo tanto em termos absolutos quanto relativos, especialmente em metrópoles como Recife, Belém, Salvador e Fortaleza, onde sua participação era mais ampla. Cresceram, paralelamente, o número e o peso dos que tinham remunerações de mais de meio a um ou de mais de um a dois salários mínimos; nesse segundo caso principalmente nas metrópoles mais industrializadas e dinâmicas, como São Paulo, Porto Alegre, Rio de Janeiro e Belo Horizonte.

Nas faixas de mais de dois a cinco ou de mais de cinco salários mínimos, as variações não foram tão grandes, uma vez que a expansão das oportunidades de trabalho ocorreu basicamente através de ocupações de baixa remuneração. Conforme estudo de Pochman, citado por Singer (2018), do total de $21 \mathrm{mi}$ Ihões de postos criados na primeira década do século XXI, 94,8\% foram com rendimentos de até 1,5 salário mínimo mensal. $E$, quando se observa a distribuição dos ocupados por grupamentos de atividade, em todas as metrópoles fica patente um crescimento daqueles que não oferecem remunerações mais elevadas, como o comércio e reparação e a construção civil, paralelamente a uma queda não desprezível do peso da indústria. Com isso, registra-se um crescimento da participação dos ocupados com ganhos superiores a dois salários apenas no Rio de Janeiro, em São Paulo e em Belo Horizonte, assim como uma queda dessa participação nas demais metrópoles estudadas, ampliando as desigualdades regionais, conforme os números da Tabela 6.

Associado à expansão dos programas de transferência de renda (como o Bolsa Família) e a outras medidas, isto levou a uma redução dos níveis de indigência e de pobreza nas áreas estudadas e no conjunto do País. De acordo com Menezes e Januzzi (2018), em 22 anos, 0 Brasil viveu dois períodos em que a pobreza e a extrema pobreza passaram por uma maior redução. 0 primeiro, em 1995, o que pode ser atribuído ao efeito da estabilização da moeda, mas cuja inflexão se restringiu a um único ano, sendo registrada, nos anos seguintes, uma tendência ascendente do número de pessoas naquela condição. Entre 2003 e 2014 os números revelam que ocorreu uma contínua redução das duas variáveis, mesmo após a crise econômica internacional de 2008, com uma continuidade da queda, alcançando os bolsões mais distantes do Brasil profundo.

Em 2015 parece haver a sinalização de que esse ciclo se interrompe e, em 2016, com os dados da PNAD contínua, observa-se um agudo empobrecimento de parte da população, retrocedendo a patamares de dez anos 
Tabela 6 - Pessoas com 10 anos ou mais de idade, ocupadas e com rendimento, por classes de rendimento mensal no trabalho principal

\begin{tabular}{|c|c|c|c|c|c|c|c|c|c|c|}
\hline \multirow{3}{*}{$\begin{array}{l}\text { Brasil e Região } \\
\text { Metropolitana }\end{array}$} & \multicolumn{10}{|c|}{ Classes de rendimento mensal do trabalho principal ${ }^{1}$} \\
\hline & \multicolumn{2}{|c|}{ Até $1 / 2$ SM } & \multicolumn{2}{|c|}{ Mais de $1 / 2$ a $1 \mathrm{SM}$} & \multicolumn{2}{|c|}{ Mais de 1 a 2 SM } & \multicolumn{2}{|c|}{ Mais de 2 a 5 SM } & \multicolumn{2}{|c|}{ Mais de $5 \mathrm{SM}$} \\
\hline & $\mathrm{N}$ & $\%$ & $\mathbf{N}$ & $\%$ & $\mathbf{N}$ & $\%$ & $\mathrm{~N}$ & $\%$ & $\mathrm{~N}$ & $\%$ \\
\hline Brasil & 6.969 & 7,4 & 18.118 & 19,1 & 31.354 & 33,1 & 20.101 & 21,2 & 7.541 & 8,0 \\
\hline Distrito Federal & 19 & 1,4 & 148 & 11,2 & 484 & 36,6 & 301 & 22,8 & 330 & 24,9 \\
\hline Belém & 51 & 5,4 & 283 & 29,9 & 306 & 32,3 & 168 & 17,8 & 66 & 7,0 \\
\hline Fortaleza & 157 & 9,1 & 597 & 34,4 & 552 & 31,8 & 251 & 14,5 & 107 & 6,2 \\
\hline Recife & 56 & 3,8 & 416 & 28,0 & 493 & 33,2 & 244 & 16,4 & 97 & 6,5 \\
\hline Salvador & 168 & 9,0 & 500 & 26,8 & 624 & 33,5 & 340 & 18,2 & 150 & 8,0 \\
\hline Belo Horizonte & 85 & 3,3 & 427 & 16,5 & 1.003 & 38,7 & 624 & 24,1 & 286 & 11,0 \\
\hline Rio de Janeiro & 120 & 2,2 & 745 & 13,5 & 2.079 & 37,8 & 1.319 & 24,0 & 649 & 11,8 \\
\hline São Paulo & 165 & 1,6 & 793 & 7,8 & 3.831 & 37,6 & 3.355 & 32,9 & 1.426 & 14,0 \\
\hline Curitiba & 41 & 2,3 & 169 & 9,6 & 640 & 36,3 & 576 & 32,6 & 217 & 12,3 \\
\hline Porto Alegre & 38 & 1,8 & 219 & 10,4 & 891 & 42,5 & 605 & 28,8 & 250 & 11,9 \\
\hline
\end{tabular}

Fonte: IBGE. Pesquisa Nacional por Amostras de Domicílio anual. Nota: ${ }^{1}$ Números absolutos em mil.

antes (2006). Na verdade, entre 2014 e 2016, 0 aumento do contingente de pessoas extremamente pobres chegou a variar $93 \%$, passando de 5,1 milhões para 10 milhões de pessoas. Em relação aos pobres, o patamar de 2016 21 milhões - é o equivalente ao de oito anos antes, em 2008, e cerca de 53\% acima do menor nível alcançado no País, de 14 milhões, em 2014. As regiões Norte e Nordeste, com maior cobertura de programas sociais, como o Bolsa Família, tiveram impacto um pouco amortecido.

Na medida em que os fatores que sustentavam essa dinâmica se esgotaram, porém, esse panorama começou a mudar, e os impactos da crise e da nova conjuntura logo se fizeram sentir. 0 desemprego cresceu nacionalmente, em todas as metrópoles e, especialmente, nos casos de Belo Horizonte, São Paulo e Fortaleza, como se observa pelos dados da Tabela 7.

No que tange à posição na ocupação, as alterações não se mostram mais expressivas, ainda que se observe uma certa tendência à redução relativa do peso dos empregados e ao crescimento dos ocupados por conta própria, condição que funciona como um refúgio de boa parcela dos desempregados e dos que não conseguiram uma situação ocupacional mais favorável no Brasil. Com a PNAD Contínua, a análise dos ocupados deixou de incluir os trabalhadores na produção para o próprio consumo e na construção para o próprio uso (categorias existentes na PNAD anual, extinta em 2015, mas que chegavam a representar $4 \%$ dos ocupados, proporção superior à de 
Tabela 7 - Pessoas de 10 anos ou mais, economicamente ativas, desempregadas, e taxa de desemprego

\begin{tabular}{l|c|c|c}
\hline \multirow{2}{*}{ Brasil e Região Metropolitana } & \multicolumn{2}{|c|}{ População (em mil) } & \multirow{2}{*}{$\begin{array}{c}\text { Taxa de Desemprego } \\
\text { (Des/PEA) }\end{array}$} \\
\cline { 2 - 3 } & Total (PEA) & Desempregados & 9,6 \\
\hline Brasil & 105.519 & 10.139 & 10,4 \\
Distrito Federal & 1.579 & 165 & 13,3 \\
Belém & 1.140 & 152 & 10,2 \\
Fortaleza & 1.918 & 195 & 15,3 \\
Recife & 1.877 & 287 & 15,8 \\
Salvador & 2.243 & 355 & 12,6 \\
Belo Horizonte & 3.017 & 379 & 11,6 \\
Rio de Janeiro & 6.246 & 727 & 11,6 \\
São Paulo & 11.539 & 1.340 & 7,5 \\
Curitiba & 1.846 & 139 & 8,7 \\
Porto Alegre & 2.316 & 201 & \\
\hline
\end{tabular}

Fonte: IBGE - Pesquisa Nacional por Amostra de Domicílios anual.

trabalhadores familiares não remunerados), e passou-se a chamar de "força de trabalho" apenas pessoas a partir de 14 anos de idade. Os empregados eram 54 milhões no primeiro trimestre de 2018, mantendo-se como grupo mais importante, mas menor do que o total apurado pela PNAD anual para 2015, seguido pelos trabalhadores por conta própria, que chegaram a quase 23 milhões de ocupados. Percebe-se um aumento relativo de trabalhadores por conta própria e uma redução de trabalhadores domésticos.

Com diferenças em termos regionais, a cobertura previdenciária persistiu crescendo até 2015 , em números tanto absolutos quanto relativos, atingindo $75,1 \%$ dos ocupados no Distrito Federal; $52,5 \%$ em Belém; $60,4 \%$ em Fortaleza; 60,4\% em Recife; 63,8\% em Salvador; $64,6 \%$ em Belo Horizonte; $75,2 \%$ em
São Paulo; 76,5\% em Curitiba; e 76,4\% em Porto Alegre, embora, no Rio de Janeiro, o peso dos contribuintes para a previdência experimentasse um pequeno decréscimo, de 69,6\% para $68,6 \%$. E, no que diz respeito aos ganhos dos trabalhadores, após as melhorias registradas nos anos anteriores, tanto no que se refere à distribuição das pessoas ocupadas por classe e rendimento mensal no trabalho principal como em termos do rendimento médio mensal dos ocupados com rendimento, os dados da PNAD não evidenciam a ocorrência de mudanças expressivas no ano em questão.

Como foi mencionado, porém, com o agravamento e a continuidade da crise, 0 baixo crescimento da economia e as novas orientações governamentais, as condições ocupacionais e sociais deterioraram-se. Com base na série histórica da PNAD anual de 2002 
até 2015, observa-se que a taxa de desemprego teve uma tendência de queda até 2012 com a crise internacional. A PNAD Contínua trimestral apresentou taxas de desemprego crescentes de 2015 até o primeiro trimestre de 2018, saindo de 7,9\% em 2015 para 13,1\% em 2018, chegando a 13,7 milhões de pessoas desempregadas $^{13}$ (Tabela 8). 0 movimento trimestral mostra as flutuações conjunturais de forma mais sensível, e pode-se perceber que, mesmo nos trimestres do ano nos quais existe uma tendência sazonal de crescimento da demanda por trabalho, como nos últimos trimestres de cada ano, as taxas mantiveram-se altas e crescentes, indicando que a pressão sobre o mercado de trabalho só tem aumentado, sem resposta através da geração de postos prometida pelo governo federal e apresentada, inclusive, como uma das justificativas para a aprovação da reforma trabalhista.

0 avanço do desemprego foi associado à ampliação da precariedade ocupacional - com a queda (em números absolutos) do contingente de empregados e, notadamente, daqueles com vínculos formalizados -, assim como ao aumento do número e do peso dos trabalhadores por conta própria, que, no ano em curso, chegaram a um quarto da força de trabalho ocupada. Destaca-se, também, o crescimento dos empregadores, que passaram a constituir uma categoria mais importante com a queda do emprego formal, levando muitos trabalhadores a tentar um negócio próprio ou a criar pequenas empresas para terceirização de atividades antes executadas diretamente pelas próprias empresas de maior porte.

Tabela 8 - Pessoas com 14 anos ou mais de idade, desempregadas, e taxas de desemprego - Brasil e Regiões Metropolitanas 2015-2018 (primeiros trimestres)

\begin{tabular}{|c|c|c|c|c|c|c|c|c|}
\hline \multirow{3}{*}{$\begin{array}{l}\text { Brasil e regiões } \\
\text { metropolitanas }\end{array}$} & \multicolumn{8}{|c|}{ Períodos (trimestres) ${ }^{1}$} \\
\hline & \multicolumn{2}{|c|}{$1^{\circ}$ trimestre 2015} & \multicolumn{2}{|c|}{$1^{\circ}$ trimestre 2016} & \multicolumn{2}{|c|}{$1^{\circ}$ trimestre 2017} & \multicolumn{2}{|c|}{$1^{\circ}$ trimestre 2018} \\
\hline & $\mathrm{N}$ & $\%$ & $\mathrm{~N}$ & $\%$ & $\mathrm{~N}$ & $\%$ & $\mathrm{~N}$ & $\%$ \\
\hline Brasil & 7.934 & 7,9 & 11.089 & 10,9 & 14.176 & 13,7 & 13.689 & 13,1 \\
\hline Distrito Federal & 165 & 10,8 & 175 & 11,2 & 234 & 14,1 & 233 & 14,0 \\
\hline Belém & 152 & 13,4 & 158 & 13,6 & 175 & 15,4 & 156 & 13,8 \\
\hline Fortaleza & 143 & 7,8 & 214 & 11,5 & 273 & 14,0 & 266 & 13,3 \\
\hline Recife & 139 & 7,7 & 248 & 13,4 & 344 & 18,0 & 367 & 19,2 \\
\hline Salvador & 335 & 14,8 & 418 & 18,4 & 420 & 18,3 & 442 & 19,2 \\
\hline Belo Horizonte & 279 & 9,7 & 378 & 13,1 & 471 & 15,8 & 479 & 15,7 \\
\hline Rio de Janeiro & 348 & 6,0 & 550 & 9,2 & 877 & 14,3 & 933 & 14,9 \\
\hline São Paulo & 976 & 8,7 & 1.458 & 12,6 & 1.847 & 15,2 & 1.854 & 14,9 \\
\hline Curitiba & 96 & 5,3 & 168 & 9,0 & 208 & 11,2 & 229 & 12,1 \\
\hline Porto Alegre & 141 & 6,3 & 186 & 8,3 & 246 & 10,9 & 231 & 10,4 \\
\hline
\end{tabular}

Fonte: IBGE. Pesquisa Nacional por Amostras de Domicílio contínua trimestral. Nota: ${ }^{1}$ Números absolutos em mil. 
Além disso, é importante destacar as pessoas que desistiram de procurar emprego; com o agravamento da crise econômica recente, deixaram de ser classificadas como desempregadas e passaram a "desalentadas". No começo de 2018, o IBGE começou a divulgar esses dados e, no primeiro trimestre desse mesmo ano, eram 4,6 milhões de pessoas de 14 anos ou mais nessa condição, contra 2 milhões no primeiro trimestre de 2012, início da série da PNAD contínua. ${ }^{14}$ Entre janeiro e março de 2018, a taxa de subutilização da força de trabalho - que agrega desocupados, subocupados (que trabalham menos horas do que poderiam) e força de trabalho potencial (no qual se enquadram os desalentados) chegou a $24,7 \%$, ou 27,7 milhões de pessoas. É o maior índice de subutilização da série histórica da PNAD contínua. Com isso, fica evidente a subestimação do desemprego quando utilizamos apenas a taxa de desocupação nas análises conjunturais sobre o mercado de trabalho brasileiro, bem como a enorme deterioração desse mercado.

A cobertura previdenciária vem tendendo a decrescer, assim como o nível de ocupação como um todo (ocupados em relação à força de trabalho) e o rendimento dos que permanecem trabalhando. A massa de rendimento médio real de todos os trabalhos recebida

Tabela 9 - Pessoas de 14 anos ou mais de idade, ocupadas por posição na ocupação no trabalho principal - Brasil e regiões metropolitanas $1^{\circ}$ trimestre de 2018

\begin{tabular}{|c|c|c|c|c|c|c|c|c|c|c|}
\hline \multirow{3}{*}{$\begin{array}{l}\text { Brasil e Região } \\
\text { Metropolitana }\end{array}$} & \multicolumn{10}{|c|}{ Posições na ocupação no trabalho principal ${ }^{1}$} \\
\hline & \multicolumn{2}{|c|}{ Empregado } & \multicolumn{2}{|c|}{$\begin{array}{l}\text { Trabalhador } \\
\text { doméstico }\end{array}$} & \multicolumn{2}{|c|}{ Empregador } & \multicolumn{2}{|c|}{ Conta própria } & \multicolumn{2}{|c|}{$\begin{array}{l}\text { Trab. familiar } \\
\text { auxiliar }\end{array}$} \\
\hline & N & $\%$ & $\mathbf{N}$ & $\%$ & $\mathrm{~N}$ & $\%$ & $\mathbf{N}$ & $\%$ & $\mathrm{~N}$ & $\%$ \\
\hline Brasil & 54.843 & 60,5 & 6.203 & 6,8 & 4.363 & 4,8 & 22.951 & 25,3 & 2.221 & 2,5 \\
\hline Distrito Federal & 1.000 & 69,9 & 105 & 7,3 & 65 & 4,5 & 252 & 17,6 & 9 & 0,6 \\
\hline Belém & 534 & 55,1 & 70 & 7,2 & 41 & 4,2 & 309 & 31,9 & 17 & 1,8 \\
\hline Fortaleza & 1.043 & 60,0 & 114 & 6,6 & 70 & 4,0 & 493 & 28,4 & 18 & 1,0 \\
\hline Recife & 980 & 63,6 & 121 & 7,9 & 61 & 4,0 & 375 & 24,4 & 4 & 0,3 \\
\hline Salvador & 1.126 & 60,5 & 130 & 7,0 & 112 & 6,0 & 469 & 25,2 & 23 & 1,2 \\
\hline Belo Horizonte & 1.664 & 64,8 & 189 & 7,4 & 135 & 5,3 & 563 & 21,9 & 16 & 0,6 \\
\hline Rio de Janeiro & 3.267 & 61,5 & 403 & 7,6 & 148 & 2,8 & 1.476 & 27,8 & 15 & 0,3 \\
\hline São Paulo & 6.924 & 65,6 & 679 & 6,4 & 619 & 5,9 & 2.248 & 21,3 & 77 & 0,7 \\
\hline Curitiba & 1.050 & 62,8 & 107 & 6,4 & 90 & 5,4 & 416 & 24,9 & 10 & 0,6 \\
\hline Porto Alegre & 1.313 & 66,2 & 111 & 5,6 & 120 & 6,0 & 434 & 21,9 & 6 & 0,3 \\
\hline
\end{tabular}

Fonte: IBGE. Pesquisa Nacional por Amostras de Domicílio anual.

Nota: ${ }^{1}$ Números absolutos em mil. 
Tabela 10 - Pessoas com 14 anos ou mais de idade, ocupadas, segundo a contribuição para a previdência em qualquer trabalho Brasil e regiões metropolitanas - 2015-2018 (primeiros trimestres)

\begin{tabular}{|c|c|c|c|c|c|c|c|c|}
\hline \multirow{3}{*}{$\begin{array}{l}\text { Brasil e regiões } \\
\text { metropolitanas }\end{array}$} & \multicolumn{8}{|c|}{ Períodos (trimestres) ${ }^{1}$} \\
\hline & \multicolumn{2}{|c|}{$1^{\circ}$ trimestre 2015} & \multicolumn{2}{|c|}{$1^{\circ}$ trimestre 2016} & \multicolumn{2}{|c|}{$1^{\circ}$ trimestre 2017} & \multicolumn{2}{|c|}{$1^{\circ}$ trimestre 2018} \\
\hline & N & $\%$ & $\mathrm{~N}$ & $\%$ & $\mathrm{~N}$ & $\%$ & $\mathrm{~N}$ & $\%$ \\
\hline Brasil & 59.715 & 64,9 & 59.537 & 65,7 & 57.799 & 65,0 & 57.748 & 63,8 \\
\hline Distrito Federal & 1.056 & 77,2 & 1.077 & 77,5 & 1.076 & 75,7 & 1.070 & 74,8 \\
\hline Belém & 520 & 52,6 & 536 & 53,5 & 515 & 53,8 & 483 & 49,8 \\
\hline Fortaleza & 1.012 & 60,0 & 993 & 60,5 & 1.029 & 61,4 & 1.016 & 58,5 \\
\hline Recife & 1.132 & 68,1 & 1.114 & 69,4 & 991 & 63,4 & 1.011 & 65,6 \\
\hline Salvador & 1.272 & 65,9 & 1.259 & 67,7 & 1.193 & 63,7 & 1.221 & 65,6 \\
\hline Belo Horizonte & 1.975 & 76,0 & 1.924 & 76,4 & 1.841 & 73,4 & 1.842 & 71,8 \\
\hline Rio de Janeiro & 4.041 & 74,7 & 4.002 & 74,0 & 3.798 & 72,0 & 3.699 & 69,7 \\
\hline São Paulo & 7.836 & 76,4 & 7.799 & 76,8 & 7.665 & 74,6 & 7.547 & 71,6 \\
\hline Curitiba & 1.323 & 77,8 & 1.346 & 78,9 & 1.256 & 75,8 & 1.207 & 72,1 \\
\hline Porto Alegre & 1.631 & 78,2 & 1.621 & 78,5 & 1.587 & 78,9 & 1.520 & 76,6 \\
\hline
\end{tabular}

Fonte: IBGE. Pesquisa Nacional por Amostras de Domicílio contínua trimestral. Nota: ${ }^{1}$ Números absolutos em mil.

pelos ocupados, que vinha aumentando 3,2\% em média de 2012 a 2014, passou a crescer apenas 1,4\% em média de 2014 a 2017, e categorias ampliadas em termos de ocupação tiveram decréscimos na média de rendimento: trabalhadores por conta própria $(-7,2 \%)$ e empregadores $(-2,1 \%)$, assim como ocupados nas atividades de alojamento e alimentação $(-11,4 \%)$, "outros serviços" (-6,1\%) e construção $(-5,1 \%)$, de 2014 a 2017. ${ }^{15}$

Segundo dados da PNAD contínua de 2017, as pessoas que faziam parte do $1 \%$ da população brasileira com os maiores rendimentos recebiam, em média, $\mathrm{R} \$ 27.213$, em
2017. Esse valor é 36,1 vezes maior que o rendimento médio dos $50 \%$ da população com os menores rendimentos ( $R \$ 754)$. Na região Nordeste essa razão foi de foi 44,9 e, na região Sul, de 25 vezes. Os $10 \%$ da população com os menores rendimentos detinham $0,7 \%$ da massa de rendimento, enquanto os $10 \%$ com os maiores rendimentos ficavam com $43,3 \%$ dessa massa, ou mais de $2 / 5$ dos rendimentos domiciliares per capita. Essa desigualdade parece contribuir para que a média do rendimento real dos ocupados se mantenha relativamente estável, conforme os dados da Tabela 11. 
Tabela 11 - Rendimento médio real das pessoas com 14 anos ou mais de idade, ocupadas com rendimento - Brasil e regiões metropolitanas 2012-2018 (primeiros trimestres)

\begin{tabular}{l|c|c|c|c|c|c|c}
\hline \multirow{2}{*}{$\begin{array}{l}\text { Brasil e regiões } \\
\text { metropolitanas }\end{array}$} & \multicolumn{9}{|c}{ Períodos (trimestres) } \\
\cline { 2 - 8 } & $\begin{array}{c}1^{\circ} \text { trimestre } \\
2012\end{array}$ & $\begin{array}{c}1^{\circ} \text { trimestre } \\
2013\end{array}$ & $\begin{array}{c}1^{\circ} \text { trimestre } \\
2014\end{array}$ & $\begin{array}{c}1^{\circ} \text { trimestre } \\
2015\end{array}$ & $\begin{array}{c}1^{\circ} \text { trimestre } \\
2016\end{array}$ & $\begin{array}{c}1^{\circ} \text { trimestre } \\
2017\end{array}$ & $\begin{array}{c}1^{\circ} \text { trimestre } \\
2018\end{array}$ \\
\hline Brasil & 1.996 & 2.045 & 2.125 & 2.126 & 2.063 & 2.110 & 2.104 \\
Distrito Federal & 4.106 & 4.010 & 3.817 & 3.962 & 3.833 & 3.659 & 3.946 \\
Belém & 1.684 & 1.703 & 1.849 & 1.625 & 1.616 & 1.726 & 1.960 \\
Fortaleza & 1.697 & 1.784 & 1.828 & 1.725 & 1.741 & 1.728 & 1.814 \\
Recife & 2.091 & 2.327 & 2.716 & 2.425 & 2.107 & 2.047 & 2.065 \\
Salvador & 2.053 & 1.949 & 2.050 & 2.089 & 2.067 & 1.989 & 2.252 \\
Belo Horizonte & 2.335 & 2.301 & 2.413 & 2.308 & 2.321 & 2.205 & 2.342 \\
Rio de Janeiro & 2.298 & 2.327 & 2.487 & 2.423 & 2.580 & 2.503 & 2.476 \\
São Paulo & 2.775 & 2.876 & 3.119 & 3.288 & 3.250 & 3.400 & 3.239 \\
Curitiba & 2.708 & 2.618 & 2.748 & 2.828 & 2.650 & 2.753 & 2.728 \\
Porto Alegre & 2.584 & 2.645 & 2.764 & 2.595 & 2.457 & 2.628 & 2.698 \\
\hline
\end{tabular}

Fonte: IBGE. Pesquisa Nacional por Amostras de Domicílio contínua trimestral.

Nota: ${ }^{1} 0$ rendimento efetivo se refere ao valor recebido no mês anterior ao da coleta e está deflacionado para o mês do último trimestre de coleta divulgado.

Afetando milhões de brasileiros nos grandes centros abordados, os problemas assinalados estão mais diretamente associados, como foi visto, à dinâmica e às políticas macroeconômicas nacionais. Contudo, não se pode desconhecer que eles vêm sendo agravados pelo caráter excludente e pelas transformações mais recentes das nossas cidades. Em que pese a consolidação progressiva de alguns dos espaços populares, com a conquista de certos equipamentos e serviços, persiste a concentração deles e das oportunidades em setores restritos do território urbano, paralelamente a uma "geografia" da pobreza e da vulnerabilidade social, agora mais complexa e heterogênea, conforme ressalta Rolnick (2015).
Nas áreas de tipo popular, a superposição de carências, a falta de perspectivas para os jovens, a expansão territorializada do tráfico de drogas (que se consolida em certas "comunidades") e a disseminação das armas de fogo têm contribuído para a degradação dos padrões de sociabilidade e para o crescimento da violência, associando a vulnerabilidade socioeconômica dos seus moradores a uma vulnerabilidade civil. 0 número de assassinatos nas grandes metrópoles brasileiras tem sido similar ou até superior ao de países em guerra, com 0 predomínio absoluto de jovens pobres, do sexo masculino, negros e moradores das periferias entre os mortos. Nas metrópoles analisadas, por exemplo, informações mais recentes sobre 
esse fenômeno mostram que ocorreram 47 mil mortes por causa externas, o que representou $30,3 \%$ do total de óbitos no País, desse total, 17,6 mil era de jovens de 15 a 29 anos e, dentre eles, 12 mil negros. ${ }^{16}$

Além disso, vem ocorrendo uma expansão crescente da órbita do mercado na organização e na dinâmica das cidades, pensadas cada vez mais como espaços para valorização do capital e como uma "máquina de crescimento" (Logan e Molotch, 1987), paralelamente a uma adesão crescente dos seus dirigentes ao denominado "empreendedorismo urbano". Analisado por autores como Harvey (2005) ou Vainer (2002), esse novo modelo de governança tem como foco a busca de uma competitividade urbana, entendida como a qualificação de cidade e a exploração de suas vantagens comparativas para disputar e atrair capitais que circulam no espaço sem fronteiras do mundo globalizado, com a oferta de diversas vantagens e subsídios aos negócios. Preocupações e intervenções de caráter social e redistributivo ficam em plano secundário, contribuindo para a ampliação das desigualdades e da vulnerabilidade ocupacional e social constatadas no presente texto.

\section{Finalizando}

Diante desse quadro, as disposições da EC 55 apontam para horizontes ainda mais sombrios. Como foi visto, essa emenda constitucional estabeleceu um novo regime fiscal segundo o qual o crescimento dos gastos da União nos próximos vinte anos não poderá ultrapassar a inflação do ano anterior, o que implica, em termos reais, um congelamento desses gastos nos patamares de 2016 até o ano de 2036. Como tanto a população quanto as demandas sociais continuarão crescendo, os recursos públicos destinados à saúde, educação, moradia, segurança e assistência social, entre outros gastos, experimentarão uma redução em termos relativos, com impactos que começam a ser discutidos por estudos, como os do IPEA, antes mencionados.

Na área da saúde, por exemplo, não foi levado em conta que o gasto público com saúde é muito baixo no Brasil, inferior, inclusive, àquele de países latino-americanos, como o Chile e a Argentina; em que a população de idosos dobrará nos próximos vinte anos, acentuando a necessidade de serviços e de verbas para o seu atendimento, e que a perda de recursos poderá ficar entre 743 bilhões e um trilhão de reais ao longo da vigência da EC, afetando especialmente os grupos, estados e municípios mais pobres, que dependem mais intensamente das transferências federais para o financiamento da saúde. ${ }^{17}$ No que tange à assistência social, com o novo regime, ocorreriam perdas no primeiro ano, e elas aumentariam sucessivamente, chegando a $54 \%$ e atingindo 868 milhões na vigência do novo regime. Com menos da metade dos recursos disponíveis para fazer frente aos serviços e benefícios atuais, haveria uma tendência à sua deterioração em termos quantitativos e qualitativos, comprometendo avanços antes obtidos e afetando ainda mais negativamente as condições de vida da população.

Expressando uma radicalização das orientações neoliberais e um projeto de longo prazo de desmonte do incipiente Estado de Bem-Estar no Brasil, a implementação dessa Emenda Constitucional ocorre 
concomitantemente com mudanças no âmbito e dos padrões de convivência das famílias, vizinhanças e comunidades, enfraquecendo os mecanismos tradicionais de apoio e proteção social e ampliando ainda mais intensamente as condições de vulnerabilidade até aqui analisadas. E, sem reversão desse quadro, tornam-se duvidosas a constituição de cidades mais justas e igualitárias, a preservação da coesão social e o próprio avanço da democracia no País.

\section{[I] https://orcid.org/0000-0002-0714-9305}

Universidade Católica do Salvador, Programa de Políticas Sociais e Cidadania. Universidade Federal da Bahia, Centro de Estudos e Pesquisas em Humanidades. Observatório das Metrópoles, Núcleo de Salvador. Salvador, BA/Brasil.

inaiammc@ufba.br

\section{[II] https://orcid.org/0000-0002-0536-2516}

Universidade Federal da Bahia, Faculdade de Filosofia e Ciências Humanas, Programa de Pós-Graduação em Ciências Sociais. Observatório das Metrópoles, Núcleo de Salvador. Salvador, BA/Brasil. claudia.monteiro.ufba@gmail.com

\section{Notas}

(1) A precarização implica não apenas o emprego incerto e a pobreza do trabalhador, mas, também, a falta de uma identidade segura baseada no trabalho. Standing (2014) define como "precariado" as pessoas desprovidas das formas de garantias perseguidas pelos socialdemocratas, partidos trabalhistas e sindicatos após a Segunda Guerra Mundial como agenda de "cidadania industrial" para a classe trabalhadora ou para o proletariado industrial, tais como emprego e renda, estabilidade e mobilidade "ascendente", segurança no trabalho, possibilidades de adquirir habilidades e conhecimentos (educação e qualificação), segurança de renda e representação.

(2) A Pesquisa Nacional por Amostra de Domicílios (PNAD) anual foi realizada pelo IBGE desde 1967 até 2015 , com o objetivo de acompanhar a realidade social, econômica e demográfica do País em períodos intercensitários. Em seu lugar, foi concebido o Sistema Integrado de Pesquisas Domiciliares (SIPD), que viria a substituir a PNAD anual e a Pesquisa Mensal de Emprego (PME). A “nova” PNAD contínua passou a ser realizada, em paralelo à PNAD, a partir de 2012, com mudanças metodológicas, temáticas e de abrangência geográfica (IBGE, 2015). Neste artigo serão analisados dados da PNAD anual de 2004, 2011 e 2015, e também dados da PNAD contínua trimestral até 2018. A sobreposição de comparações entre as duas pesquisas nos serve para verificar a coerência da análise, mesmo com a mudança metodológica. 
(3) Entre essas últimas iniciativas estão a Política Nacional de Economia Solidária e o Programa Nacional de Apoio à Agricultura Familiar - Pronaf.

(4) Conforme estudo do Dieese, citado por Montalli e Lessa (2016), entre abril de 2003 a janeiro de 2010, o salário mínimo teve um aumento real de 53,7\%, beneficiando cerca de 46,1 milhões de pessoas que tinham rendimentos referenciados a esse salário.

(5) Com isso, as camadas médias tiveram expectativas frustradas, com uma redução do valor dos seus diplomas e escassas oportunidades de uma inserção profissional mais qualificada. Com o crescimento da participação, tanto dos mais pobres como dos mais ricos, caiu a participação desses segmentos na renda total do País, alimentando uma insatisfação que terminou desaguando na crise política e contribuindo para o seu agravamento.

(6) Dados da Secretaria do Tesouro Nacional, incluindo as renúncias fiscais. Diisponível em: http:// www.tesouro.fazenda.gov.br/documents/10180/318974/Gasto+Social+Governo+Central/ c4c3d5b6-8791-46fb-b5e9-57a016db24ec. Acesso em: 8 jul 2018.

(7) De acordo com a OCDE. Dados disponíveis em: https://www.oecd.org/centrodemexico/medios/ gasto-publico-social-ocde.htm. Acesso em: 8 jul 2018.

(8) Dados da PNAD Anual do IBGE.

(9) O Brasil não tem uma linha oficial de pobreza; há diversas linhas que atendem a vários objetivos. Chega-se a 4,2\% da população, segundo o recorte de pobreza extrema do Bolsa Família (85 reais mensais), 6,5\% no recorte de pobreza extrema global do Banco Mundial (1,90 dólar, por dia, ou 6,30 reais, o que equivale a 134 reais mensais) e 12,1\% com um quarto de salário mínimo familiar per capita. Recortes de pobreza mais altos incluem a população com até meio salário mínimo familiar per capita $(29,9 \%)$, e a linha do Banco Mundial que leva em conta o nível de desenvolvimento brasileiro (e da América Latina) é de 5,5 dólares por dia.

(10) Conjunto de investigações sobre corrupção e lavagem de dinheiro iniciado em 2014 pela Polícia Federal brasileira, envolvendo políticos, empresários e gestores públicos.

(11) Sobre a dinâmica da urbanização e da metropolização do Brasil, ver Ribeiro (2017a). No capítulo em que discute essa dinâmica o autor assinala que em 2010 existiam 35 regiões metropolitanas (RMS) e 3 regiões integradas de desenvolvimento econômico (RIDES) oficiais no Brasil. Institucionalizadas sem critérios claros, objetivos e consistentes, porém, a grande maioria delas não teria efetivamente, um caráter metropolitano, considerando a dimensão da sua população e a limitada expressão das suas funções. A partir de critérios como tamanho e concentração populacional e econômica, centralidade, inserção na economia, poder de direção e gestão pública, o referido autor identifica a existência de apenas 15 espaços com esse caráter no país: São Paulo, Rio de Janeiro, Belo Horizonte, Porto Alegre, Distrito Federal, Curitiba, Salvador, Recife, Fortaleza, Campinas, Manaus, Goiânia, Belém e Florianópolis. O texto acima indicado também apresenta considerações relevantes sobre as transformações desses espaços na fase contemporânea.

(12) Calculados com dados do Instituto de Pesquisa Econômica Aplicada - IPEA. Disponível em: www. ipeadata.gov.br. Acesso em: 5 jul 2018. 
(13) Conforme ressaltado anteriormente, as comparações com os indicadores da PNAD contínua devem ser feitas levando-se em consideração algumas mudanças metodológicas. De forma simplificada, a PNAD contínua passou a considerar as pessoas em idade para trabalhar aquelas com 14 anos ou mais (na PNAD anual eram consideradas as pessoas com 10 anos ou mais de idade); o trabalho na produção para o próprio consumo e na construção para o próprio uso deixou de ser considerado ocupação.

(14) O IBGE denomina de "força de trabalho potencial" as pessoas de 14 anos ou mais de idade que: a) realizaram busca efetiva por trabalho, mas não se encontravam disponíveis para trabalhar na semana de referência; b) pessoas que não realizaram busca efetiva por trabalho, mas gostariam de ter um trabalho e estavam disponíveis para trabalhar na semana de referência. Ou seja, querem trabalhar, mas deixaram de procurar trabalho por não conseguirem ocupação adequada, não ter experiência ou qualificação, ser considerado muito jovem ou idoso ou não haver trabalho no lugar onde mora. Para ser estatisticamente desalentado, é preciso estar disponível e disposto a assumir uma vaga assim que ela surgir.

(15) Dados apresentados pela IBGE na Retrospectiva 2012-2017 da Pesquisa Nacional por Amostra de Domicílios contínua - PNAD contínua, divulgada em 31 de janeiro de 2018.Disponível em https://www.ibge.gov.br/estatisticas-novoportal/sociais/trabalho/9171-pesquisa-nacional-poramostra-de-domicilios-continua-mensal.html?=\&t=downloads. Acesso em: 10 jul 2018.

(16) Dados do Sistema de Informações sobre Mortalidade - SIM, do Ministério da Saúde. Disponível em http://tabnet.datasus.gov.br/cgi/deftohtm.exe?sim/cnv/ext10br.def. Acesso em 10 jul 2018. O grupo de Causas externas (CID 10) inclui: acidentes de transporte, agressões, eventos cuja intenção é indeterminada, intervenções legais e operações de guerra, complicações de assistência médica e cirúrgica, sequelas de causas externas e fatores suplementares relacionados a outras causas.

(17) Mais cedo do que se poderia esperar, os efeitos adversos do referido regime se fizeram sentir, pois, para atender às reivindicações do movimento de caminhoneiros pela redução do preço do óleo diesel, o governo federal cortou verbas dos programas sociais que envolveram, entre outros recursos, 135 milhões destinados ao Sistema Único de Saúde. E, como adverte Carvalho (2018, p. 159), "se o PIB brasileiro crescer nos próximos vinte anos no ritmo dos anos 1980 e 1990, a EC do teto de gastos, se mantida, nos levará de um percentual de gastos públicos em relação ao PIB da ordem de $40 \%$ para $25 \%$, patamar semelhante ao verificado em Burkina Faso ou no Afeganistão, e, se crescermos às taxas mais altas que vigoraram nos anos 2000, o percentual será ainda menor, de ordem de 12\%, o que nos aproximará de países como o Cambodja e Camarões". 


\section{Referências}

BORGES, A. M. de C. (2016). Os novos horizontes de exploração do trabalho, da precariedade e da desproteção. Caderno do CEAS, n. 239, pp. 713-741.

CARDOSO, A. N. (2004). A década neoliberal e a crise dos sindicatos no Brasil. São Paulo, Boitempo.

CARDOSO Jr., J. C. (2011). Planejamento governamental e gestão pública no Brasil: elementos para ressignificar o debate e capacitar o Estado. Texto para Discussão n. 1584, Brasília, Instituto de Pesquisa Econômica Aplicada (IPEA), março.

CARVALHO, I. M. M. de (2006). Globalização, metrópoles e crise social no Brasil. Revista EURE. Santiago do Chile, v. XXXII, n. 95, pp. 5-20.

CARVALHO, L. (2018). Valsa brasileira: do boom ao caos da economia. São Paulo, Todavia.

CASTEL, R. (2012). El ascenso de las incertitumbres. Trabajo, proteciones, estatuto del individuo. Buenos Aires, Fondo de Cultura Economica.

CHADE, J. (2018). Por reforma trabalhista, OIT coloca Brasil em 'lista suja' de violações. Portal Estadão, Economia \& Mercado, 28 de maio. Disponível em: <https://economia.estadao.com.br/noticias/ geral,por-reforma-trabalhista-oit-coloca-brasil-em-lista-suja-de-violacoes, 70002327317>. Acesso em: 29 maio 2018.

DEDECCA, C. S. (2015). A redução da desigualdade e seus desafios. Texto para discussão, n. 2031. Brasília e Rio de Janeiro, Ipea.

FARIA, V. E. (1976). O sistema urbano brasileiro: um resumo das características e tendências recentes. Estudos CEBRAP, n. 18. São Paulo.

HARVEY, D. (2005). A produção capitalista do espaço. São Paulo, Annablume.

IPEA (2016a). Os impactos do novo regime fiscal e suas implicações para a política de assistência social no Brasil. Brasília, Nota Técnica, n. 28.

(2016b). O novo regime fiscal e suas implicações para a política de assistência social no Brasil. Brasília, Nota Técnica, n. 27.

IVO, A. B. L. (2008). Viver por um fio: pobreza e política social. São Paulo, Annablume/ Salvador, CRHUFBA.

KERTENETZKY, C. L. (2012). O Estado de Bem-Estar Social na idade da razão: a reinvenção do Estado Social no mundo contemporâneo. Rio de Janeiro, Elsevier.

KOWARICK, L. (1979). A espoliação urbana. Rio de Janeiro, Paz e Terra.

(2008). Viver em risco: sobre a vulnerabilidade socioeconômica e civil. São Paulo, Editora 34.

LOGAN, J. e MOLOTCH, H. (1987). Urban Fortunes: the political economy of place. Califórnia, University of California Press.

MENEZES, F. e JANUZZI, P. (2018). Com o aumento da extrema pobreza, Brasil retrocede dez anos em dois. Teoria e Debate. Edição 170. Disponível em: https://teoriaedebate.org.br/2018/03/07/como-aumento-da-extrema-pobreza-brasil-retrocede-dez-anos-em-dois/. Acesso em: 4 jul 2018.

MONTALLI, L. e LESSA, L. H. (2016). Pobreza e mobilidade de renda nas regiões metropolitanas brasileiras. Cadernos Metrópole. São Paulo, v. 18, n. 16, pp. 503-533. 
MOURA, R.; DELGADO, P.; DESCHAMPS, M. e CARDOSO, N. A. (2004). “A realidade das áreas metropolitanas e seus desafios na federação brasileira: diagnóstico socioeconômico e da estrutura de gestão. In: SEMINÁRIO INTERNACIONAL DESAFIOS DAS REGIÕES METROPOLITANAS EM PAÍSES FEDERADOS. Brasília.

POCHMANN, M. (2001). O emprego na globalização. A nova divisão internacional do trabalho e os caminhos que o Brasil escolheu. São Paulo, Boitempo.

POCHMANN, M. et al. 2004). Atlas da exclusão social no Brasil. São Paulo, Cortez.

POLANYI, K. (2000). A grande transformação: as origens da nossa época. Rio de Janeiro, Elsevier.

RIBEIRO, L. C. de Q. (2017a). A metrópole em questão: desafios da transição urbana. Rio de Janeiro, Letra Capital e Observatório das Metrópoles.

(2017b). As metrópoles e o direito à cidade na inflexão neoliberal na ordem urbana brasileira. Rio de Janeiro, Observatório das Metrópoles/INCT.

ROLNIK, R. (2015). Guerra dos lugares. A colonização da terra e da moradia na era das finanças. São Paulo, Boitempo.

SINGER, A. (2018). O lulismo em crise: um quebra-cabeças do período Dilma - 2011-2016. São Paulo, Companhia das Letras.

SINGER, A. e LOUREIRO, I. (2017). As contradições do lulismo: a que ponto chegamos? São Paulo, Boitempo Editorial.

STANDING, G. (2014). O precariado: a nova classe perigosa. Belo Horizonte, Autêntica.

VAINER, C. (2002). "Pátria, empresa e mercadoria: notas sobre a estratégia discursiva do planejamento estratégico urbano”. In: ARANTES, O.; VAINER, C. e MARICATO, E. (orgs.). A cidade do pensamento único. Petrópolis, Vozes.

VELTZ, P. (1996). Mondialisation, villes et territoires: I'economie d'el archipel. Paris, Press Universitaire de France.

VILLAÇA, F. (1998). Espaço intra-urbano no Brasil. São Paulo, Studio Nobel e Fapesp.

Texto recebido em $22 / j u l / 2018$

Texto aprovado em 12/set/2018 